\title{
Criação de jornal na avaliação de aspectos comportamentais ligados à gestão de pessoas
}

\author{
Neusa Cavedon*
}

\section{Resumo}

Este artigo procura apresentar uma experiência de avaliação educacional, alinhada com uma lógica específica desenvolvida pelos estudos educacionais, na qual a avaliação deve servir como um feedback para os professores e para as escolas. Essa visão (da avaliação baseada em diagnóstico e formativa) procura desenvolver nos discentes a capacidade de planejar, questionar, criticar, descobrir, criar, comunicar, transformar e conhecer, entre outras possibilidades.

Palavras-chave: instrumento de avaliação; didática; ensino- aprendizagem.

\section{Abstract}

The aim of this paper is to present an experience in the educational assessment field. Such experience comes aligned with a specific logic developed by educational studies, according to which assessment should be used as feedback for teachers and schools. This view - of a diagnostic and formative assessment - proposes to develop students' ability to planning, questioning, criticizing, discovering, creating, communicating, transforming, learning, and others.

Key words: assessment instrument, didactic, teaching, learning

\section{Introdução}

A avaliação do desempenho dos alunos sempre foi um aspecto que me preocupou: provas, trabalhos, participação em aula, realização de exercícios em classe e avaliação, seja em grupo ou individual. Afinal, qual a melhor maneira de verificar o desempenho dos discentes? O mundo empresarial, através da mídia e de outros canais, vem expressando o seu descontentamento com a atuação dos egressos nas atividades de cunho coletivo. Então, parece ser relevante a realização de trabalhos que possam ser avaliados pela atuação coletiva. Mas será que essa é uma forma justa? Essas dúvidas me assolavam e resolvi experimentar um caminho que permitisse avaliar a participação coletiva e que também viabilizasse a identificação e o reconhecimento do desempenho individual. Dessa perspectiva, pensei a elaboração de um jornal como passível de implementação de um processo avaliativo que contemplasse a dimensão individual e a coletiva.

A primeira vez em que solicitei aos alunos para que elaborassem um jornal foi numa universidade particular com turmas do quinto semestre dos cursos de Administração de Empresas e de Administração de Recursos Humanos, na disciplina de gestão e cultura organizacional. Mais tarde, atuando numa universidade pública como docente da disciplina psicologia aplicada à administração, para alunos do terceiro semestre do curso de Administração, também, passei a incluir essa atividade como trabalho final.

\footnotetext{
* Doutora em Administração pela Universidade Federal do Rio Grande do Sul. Professora Adjunta da Universidade Federal do Rio Grande do Sul. Endereço: Av. Washington Luiz, 855, sala 425 - Centro - Porto Alegre/RS - CEP: 90010-46. E-mail: nrcavedon@ ea.ufrgs.br.

** Artigo recebido em setembro de 2006 e aceito para publicação em novembro de 2006.
} 


\section{Avaliação: aspectos teóricos}

De acordo com Sant'Anna (1983), a expressão "avaliar os alunos" incorre numa imprecisão lingüística que acaba por gerar angústia em alunos e professores, daí decorrendo manifestações por parte de docentes do tipo "não gosto de avaliar os alunos", "para mim a parte mais difícil da docência é a avaliação dos alunos". Por seu turno, os alunos dizem: "como pude sair tão mal na prova?", "eu não sou capaz de entender isso". A referida autora adverte que o que está em jogo na avaliação educacional não é a "avaliação do aluno", mas, sim, atributos ou desempenhos. O professor avalia de forma parcial e transitória o resultado da aprendizagem. Assim, não é possível classificar os alunos em "bons" ou "maus", pois ao agir de tal modo, o docente está fugindo daquilo a que se propõe o ambiente educacional, ou seja, encontrar possíveis distorções no processo de ensino-aprendizagem e atuar de modo a corrigilas.

Mais do que uma preocupação em obter feedback, a avaliação é uma atividade que visa atender a burocracia do espaço organizacional. Nas palavras de Sant'Anna (1983, p.85):

Isto se torna evidente no uso feito dos resultados de avaliação da instrução que os professores devem entregar a órgãos administrativos das escolas, para registro. Se mais fielmente cumprissem os propósitos educacionais da avaliação, teriam os professores e alunos reais oportunidades de confrontar suas idéias sobre desempenhos, revisar e reintegrar conteúdos, enfim, de realimentar o processo ensinoaprendizagem para alcance dos objetivos previstos e do sucesso escolar.

Por seu turno, Ilza Sant'Anna (1995, p.16) define avaliar: "como atribuir algum valor, e não implicar em desvalorizar". De acordo com essa concepção, é preciso que sejam utilizados instrumentos de cunho qualitativo ou quantitativo que permitam verificar em que medida o objetivo da aprendizagem foi alcançado. A idéia não é punir o aluno ou o professor - pois tanto um quanto o outro, em certos casos, costumam ser culpabilizados pelo baixo rendimento na aprendizagem do aluno - mas, sim, conscientizar ambos de que a responsabilidade é de cada um e também coletiva. Para Sant'Anna (1995, p.17):

Comparando com um time de futebol ou qualquer outro esporte, o participante é avaliado individualmente e também a produtividade do grupo é considerada, incluindo-se o técnico responsável. $O$ resultado determinará a confirmação ou uso de novas estratégias. Ninguém é punido, mas todos são responsáveis pelo produto, seja para comemorar ou admitir a derrota, buscando novas alternativas, ou empenhando-se com mais intensidade no alcance do objetivo.

É esperado que o discente de terceiro grau, no fim do processo de aprendizagem, revele em seu perfil características como: ser planejador, questionador, crítico, descobridor, animador, criador, comunicador, transformador, avaliador, conhecedor e um educador a serviço de outros educadores (SANT'ANNA, 1995).

A partir desses pressupostos, optou-se por proceder à avaliação através de um instrumento, um jornal, que viabilizasse o desenvolvimento de habilidades e conhecimentos individuais e coletivos e que servisse de indicativo sobre as possíveis correções a serem implementadas no processo de ensino-aprendizagem.

\section{Sugestões para a elaboração de um jornal}

A elaboração de um jornal - nos moldes daqueles que circulam dentro das organizações - tem por objetivo que os grupos compostos por no máximo seis alunos, em turmas de 40 ou 50, possam escolher, dentre o elenco de temáticas desenvolvidas ao longo do semestre (este trabalho deve ser solicitado como exercício final da disciplina ), aquelas que mais chamaram sua atenção.

Cada componente do grupo deve se responsabilizar pela elaboração de no mínimo uma matéria, que precisa conter a fonte de onde ele retirou as informações e o seu nome; portanto, uma matéria assinada. Os alunos podem se 
dedicar à produção de mais de uma matéria; com isso, é estabelecido um limite mínimo de matérias por aluno (uma) e não há limite máximo. Dentre as opções apresentadas estão:

- entrevistas com executivos, profissionais ou professores;

- resenhas de livros e artigos acadêmicos;

- palavras cruzadas versando sobre o tema escolhido;

- charge;

- horóscopo; ou

- pesquisas.

Tudo tem de estar conectado com o tema escolhido, e as matérias, dentro do possível, apresentando um posicionamento crítico por parte dos alunos-autores.

\section{Apoio em termos de técnicas de jornalismo}

No caso da disciplina ser partilhada com alunos da área de Comunicação, é interessante solicitar-lhes uma palestra, onde algumas técnicas básicas de jornalismo possam ser repassadas para os colegas de outras áreas. Caso não haja dentre os discentes ninguém ligado à Comunicação Social, é conveniente que se convide um professor ou aluno da área para passar certos conhecimentos indispensáveis na elaboração de um jornal.

\section{Trabalho coletivo, temas e acompanhamento}

Esse trabalho exige um esforço coletivo que tem início com a escolha, pelo grupo, do nome do jornal. A elaboração do editorial também deve ser coletiva, bem como a diagramação e o encadeamento das matérias. A essas características conjuntas, o professor atribui uma nota ou conceito e depois faz uma avaliação da(s) matéria(s) produzida(s) individualmente pelos discentes. A nota final será determinada pela média da nota individual mais a nota coletiva.

As habilidades que são teoricamente apresentadas aos alunos como relevantes ao exercício da gestão organizacional podem ser colocadas como objeto de avaliação na realização da tarefa. Por exemplo, criatividade, responsabilidade, capacidade de expressão verbal e escrita, integração com os demais membros do grupo, capacidade de gerenciar conflitos, liderança etc. A adequada utilização dessas habilidades vai se refletir no resultado final, no produto em si, ou seja, num jornal que tenha coerência, onde não haja duplicidade nas matérias, que apresente algo inovador e com profundidade em seu conteúdo.

Em termos de apresentação é desejável uma diagramação adequada, bem como português e digitação devidamente revisados. Em relação à matéria elaborada por cada um, os critérios poderão incluir a capacidade de selecionar as fontes de consulta, a visão crítica, a redação correta, a iniciativa em ampliar o conhecimento e outros critérios que forem julgados relevantes e antecipadamente esclarecidos aos alunos como importantes para o processo de avaliação.

Passado algum tempo realizando essa forma de avaliação, optei por solicitar que cada grupo trabalhe com uma temática diferente daquela dos demais grupos. Assim, cada grupo pode optar por desenvolver uma das seguintes temáticas: liderança, comunicação, grupos, motivação, poder, mudança, aprendizagem, cultura organizacional, estresse e outros ligados à psicologia aplicada ao mundo organizacional.

É também conveniente que o professor não recorra a essa forma de avaliação em semestres seguidos. A alternância de semestres permite que novas produções acadêmicas possam ser incorporadas pelos alunos, evitando uma 
repetição; especialmente, se o professor conseguir na sua instituição que esse material venha a ser publicado e veiculado entre os demais alunos do curso.

Todavia, em caso de publicação, é bom contatar um jornalista responsável, para que o mesmo possa fazer a revisão e também garanta que não se está entrando em seara alheia, o que pode gerar problemas quanto ao exercício de uma atividade profissional para a qual não se tem formação.

Uma advertência dos alunos diz respeito ao tempo dispensado para a realização da tarefa. Na verdade, é preciso disponibilizar algumas aulas no final do semestre, para que eles, em sala de aula, possam trazer os artigos, roteiros de entrevistas e instrumentos de pesquisa para a apreciação do professor que estará sempre presente, orientando a realização da atividade.

No caso do jornal que aparece parcialmente ilustrando esse artigo, o grupo optou pelo tema "estresse". Escolhido o tema, os integrantes procuraram dividir as tarefas, diversificando as matérias a serem veiculadas. Assim, cada integrante, de acordo com seu perfil e interesse, responsabilizou-se por uma ou mais atividades dentre as possíveis escolhas: elaborar uma resenha, a coluna de cartas do leitor, entrevistas, uma mini pesquisa etc. Definidas as tarefas de cada membro do grupo, a seguir, fui consultada pelos alunos sobre as fontes bibliográficas. Recomendei que utilizassem periódicos acadêmicos, disponibilizei livros da minha biblioteca pessoal, destaquei a capacidade seletiva que eles deveriam ter em relação às fontes, sugeri navegar pela Internet em busca de sites sobre o tema, sugeri nomes de profissionais que poderiam ser entrevistados, verifiquei se o instrumento da coleta de dados para a execução da pesquisa e a forma como a mesma seria realizada estavam corretos, alertei para limitações da pesquisa; enfim, a interlocução professora/alunos foi intensa e constante.

Além de apresentar o jornal impresso, os alunos podem numa aula, apresentar o jornal verbalmente para os demais colegas de turma. Nessa ocasião, as dúvidas e discussões devem ser articuladas entre discentes e o docente, de modo que esse último atue como mediador e possa elucidar possíveis incorreções na compreensão da teoria ou, mesmo, diante de uma situação prática narrada.

O resultado tem sido uma aprendizagem adequada por parte dos discentes e um envolvimento do grupo na execução da atividade, que tende a suplantar as expectativas, em face do empenho demonstrado em trazer um conteúdo teoricamente relevante, associado a uma preocupação com a diagramação, modos de atuar que visam atrair o leitor, tal como ocorre com um veículo de grande circulação.

\section{Conclusão}

Consoante com as teorizações defendidas pelos teóricos da educação, no sentido de que avaliar não é punir, o jornal configura-se como um instrumento que alia capacidade técnica, domínio de conteúdos, habilidade de relacionamento interpessoal, de trabalhar em grupo, de planejamento, coordenação, liderança, motivação e de criatividade.

Inúmeras habilidades e conhecimentos são acionados nessa atividade que reúne a cientificidade na abordagem de determinados conteúdos a uma forma mais livre de expressão dessa apropriação do conhecimento, o que permite ao aluno extrapolar os limites trabalhados em sala de aula, indo além, até mesmo na iniciativa de se arriscar no universo da pesquisa. 


\section{Referências}

SANTANNA, F. M. Uma análise crítica da avaliação educacional. Universidade Federal do Rio Grande do Sul. Pró-Reitoria de Graduação. Programa de Apoio ao Desenvolvimento do Ensino Superior. Avaliação de aprendizagem: enfoques teóricos. Porto Alegre, UFRGS, 1983.

SANTANNA, I. M. Por que avaliar? Como avaliar?: critérios e instrumentos. Petrópolis, Vozes, 1995.

\section{Exemplo de um jornal sobre estresse}

Como ilustração, nas próximas páginas é apresentado um dos jornais elaborados por um grupo de alunas, no primeiro semestre de 2003, na disciplina psicologia aplicada à administração. Como docente, devo dizer que me sinto feliz e orgulhosa ao ver a criatividade dos alunos e seu empenho para enfrentar esse desafio. 


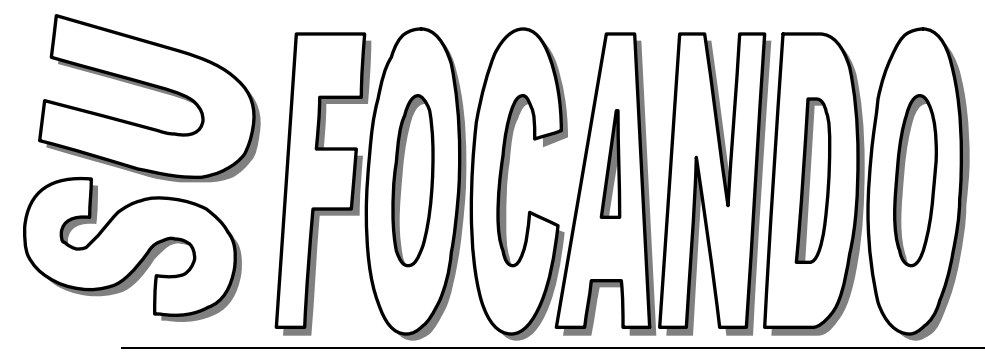

Ano I - N 01
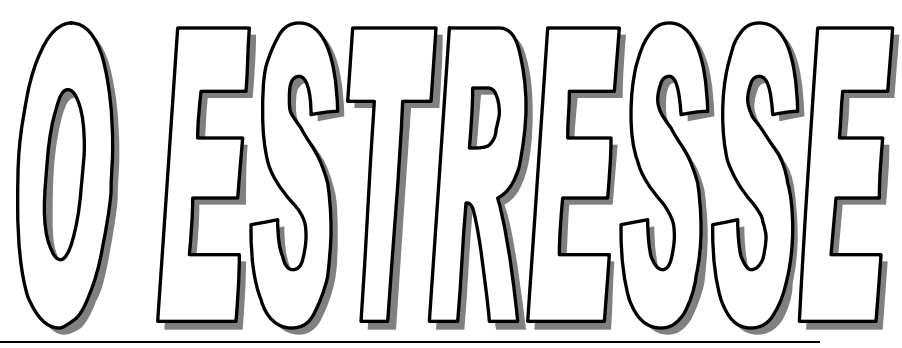

Porto Alegre, 15 de Agosto de 2003
Variáveis do Estresse?!

Você sabe realmente o que tem deixado você estressado no trabalho?

Pg. 3

Teste o seu nível de estresse na pg. 4

A dor é psicológica:

conheça os efeitos e as conseqüências do estresse Pg. 7

Buscar soluções é a melhor forma de "desestressar-se" Pg. 12

\section{EXCLUSIVO:}

Entrevista com Ana Maria Rossi, presidente da ISMA no Brasil Pg. 6

\section{Alunos da UFRGS: como anda o nível de estresse entre os universitários?}

Pg. 8

Como o estresse pode diminuir a sua imunidade Pg. 4

Pg. 9

\section{O estresse no ambiente de trabalho}

Estresse: é melhor prevenir Pg. 10

Terapias Alternativas que ajudam no combate ao estresse Pg. 11 


\section{Editorial}

Em face da correria do dia-a-dia e às rotinas e ambientes complexos das organizações, o Jornal SuFocando o Estresse traz informações que buscam ajudá-lo a conviver com esse mal chamado estresse.

Assim, nessa primeira, única e exclusiva edição você poderá compreender o que é o estresse e conhecer as suas causas lendo as reportagens "Variáveis do Estresse" e "Estresse no Trabalho". Nas matérias "Dor é psicológica" e "Imunidade" serão apresentados os efeitos e as consequiências do estresse.

Em pesquisa realizada, por uma de nossas correspondentes com os alunos da Escola de Administração da Universidade Federal do Rio Grande do Sul, foi avaliado o nível de estresse dos estudantes. Os resultados você confere na página 8. Aproveite também para fazer o teste "Será que é estresse?" e saber se você anda estressado. Depois de conhecer melhor o assunto, você vai saber como tratá-lo, ou melhor, como prevenir-se contra essa doença.

\section{As Editoras}

\begin{tabular}{|c|}
\hline EXPEDIENTE \\
\hline Esta é uma publicação da disciplina de Psicologia \\
aplicada à Administração, ministrada pela Profa. \\
Neusa Cavedon, pelos alunos da Escola de \\
Administração da Universidade Federal do Rio \\
Grande do Sul - EA/UFRGS \\
Washington Luis, 885 \\
Porto Alegre - RS - Brasil \\
www.ea.ufrgs.br \\
Produção, editoração e redação: \\
Bruna Deboni (bruna.deboni @ terra.com.br) \\
Carolina Wosiack (corpoealma @ brturbo.com.br) \\
Gabriela Gonçalves \\
(gabi_gonçalves@ @otmail.com) \\
Liriane Piffero (liriane@ @ myway.com.br) \\
Luisa Ludwig (luludwig@ hotmail.com) \\
Rafaella Tabajara (rafatabajara@ @hotmail.com) \\
\hline
\end{tabular}

\section{Perguntas do Leitor}

A felicidade é importante para o fortalecimento do sistema de imunidade da pessoa?

Um estudo feito recentemente pela Universidade de Nova York demonstra que os eventos positivos do cotidiano, como o reconhecimento pelo desempenho no trabalho ou um convite para jantar, estimulam a produção das células de imunidade do organismo. E esse efeito dura 48 horas. Por outro lado, os eventos negativos, como ser criticada ou não ser incluída em uma atividade da qual gostaria de participar, suprimem as células de imunidade, mas por apenas 24 horas. Isso indica que o impacto positivo da felicidade no sistema de imunidade é mais poderoso do que o negativo. Portanto, pense que a maneira como lida com as pequenas coisas do dia-a-dia pode ser o seu salvavidas imunológico.

Ando muito esquecida. Isso pode sinalizar que estou estressada?

$\mathrm{O}$ esquecimento e a falta de atenção podem ser causados ou associados ao stress. No entanto, podem também estar relacionados a outros problemas emocionais como a ansiedade e a depressão. Inúmeros estudos científicos indicam que o nível de estresse e o estilo de vida da pessoa determinam $60 \%$ das doenças. Uma percentagem alta, se considerarmos que $80 \%$ das visitas feitas a médicos são devido a sintomas associados ao estresse. Se o estresse é realmente a origem dos seus sintomas, avalie as causas e faça mudanças comportamentais e no seu estilo de vida. Lembrese, o sintoma é um sinal de alerta.

Qual é a causa que apresenta os maiores riscos para a saúde dos funcionários de uma empresa?

Muitos sintomas de estresse negativo - dores musculares, pressão arterial alta, fadiga, taquicardia, ansiedade e angústia - têm sido atribuídos ao acúmulo das pressões profissionais. Qualquer situação independente de estar vinculada ao trabalho pode ser percebida como estressante. No entanto, alguns epidemiologistas americanos apontam certas características do trabalho como prováveis causas de estresse. A sensação da falta de controle é a grande responsável pelas doenças causadas pelo estresse. Assim, o funcionário que tem grandes responsabilidades, mas pouca autonomia para tomar decisões é o que corre os maiores riscos do estresse negativo. Outra fonte de 
tensão é a pessoa não ter uma identidade pessoal definida.

Embora me organize para tirar minhas férias, sempre me estresso com o acúmulo de preparativos. Tirar férias realmente causa estresse?

Sem dúvida, tirar férias é estressante. Um estudo da International Stress Management Association no Brasil (ISMA-BR) com 556 pessoas revela que $12 \%$ delas se sentiam estressadas com a aproximação das férias. $\mathrm{O}$ estresse de férias é parcialmente causado pelo planejamento e preparação que requerem, as mudanças impostas aos hábitos diários (hora de dormir, dieta e exercício físico). Para diminuir o seu nível de estresse delegue tarefas, priorize suas atividades e estabeleça seus objetivos para esse período. Acima de tudo, seja flexível, permitindo-se trocar de planos, se necessário. Seguir uma agenda rígida quando você gostaria de estar fazendo outra coisa é frustrante.

\section{Respostas de Liriane Piffero}
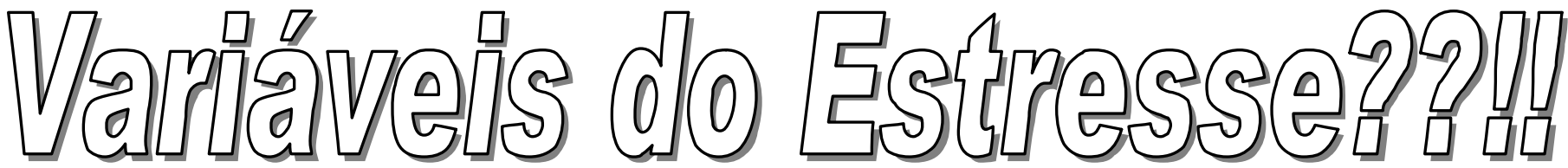

O estresse no trabalho pode ser ocasionado por inúmeros motivos ou, curiosamente, por inúmeras "variáveis" que são determinadas pelo cargo, pelo ambiente, pela empresa, pela tarefa e, principalmente, pelo indivíduo. Assim, o alto nível de estresse dos funcionários de uma organização pode depender tanto dos fatores de pressão como das variáveis individuais do estresse.

Os fatores de pressão são aqueles proporcionados, geralmente, pela empresa. O papel gerencial é um desses fatores, já que a pessoa a quem se é subordinada deve servir como "espelho" para o funcionário. O "chefe" que exercer esse papel, de acordo com o modo como trata seus subordinados (se delega tarefas, se existe uma confiança mútua, se existe uma relação informal, entre outros), exerce uma força definitiva na motivação do indivíduo quanto ao seu trabalho. Se o papel gerencial não for também um papel motivacional e, inclusive, exercer e mostrar autoridade, pode vir a deixar o funcionário frustrado, e, conseqüientemente, desmotivado e estressado.

Além do papel gerencial, o papel que o próprio indivíduo exerce na organização também é um fator importantíssimo. Ele deve se sentir valorizado, sentir que seu trabalho colabora para o crescimento da empresa.

Também o relacionamento inter-pessoal é, hoje, fundamental para o bom andamento das empresas, já que permite a integração dos funcionários, melhorando a produtividade de cada um. Assim, também vale para o indivíduo que não se sente sozinho e vai motivado para o trabalho.

Para o funcionário, é importante criar e realizar expectativas quanto à sua carreira na empresa. Se o indivíduo sabe que, ao realizar bem o seu trabalho, poderá ter uma promoção ou aumento de salário, por exemplo, ele é estimulado a sempre dar mais de si para obter tais recompensas. Além disso, a realização do indivíduo quanto à profissão escolhida e carreira a ser seguida também influi no nível de motivação.

$\mathrm{O}$ estresse também surge das variáveis individuais, como o comportamento dos indivíduos nas empresas. A forma de agir e o comportamento do funcionário frente a decisões tomadas e problemas que surgem no cotidiano da empresa deve ser adequada para a empresa, para que assim ele se sinta parte. Esse comportamento advém da atitude que o indivíduo tem para com a vida e a forma como encara as coisas.

O grau de ambição da pessoa é outra variável do indivíduo que pode ocasionar estresse. Uma pessoa mais humilde se contenta com um pouco menos, enquanto que uma pessoa mais ambiciosa tende a se estressar mais, já que seus objetivos são mais difíceis de alcançar.
Para lidar com tudo isso, o indivíduo tem que ter um "lócus" de controle, algo internalizado que o ajude a combater o estresse e as insistentes razões que aparecem no nosso dia-a-dia para nos deixar estressados, ou seja, o nível de estresse depende dos mecanismos que cada um tem para combatê-lo.

Além dos mecanismos, o indivíduo deve saber gerenciar seu tempo para que consiga realizar tudo o que precisa para viver e se sentir bem. $\mathrm{O}$ tempo que a pessoa passa em casa também deve ser calmo e precioso.

O primeiro sinal de estresse é a insatisfação com o trabalho e alguma debilitação física ou mental, ou ambas, ocasionada por este. Assim, vemos que o indivíduo que por qualquer uma das causas acima ou por falta delas se sinta desmotivado, fica mais fragilizado e exposto ao estresse.

Se você se identifica com a maioria dos aspectos acima citados, cuidado, você anda se estressando muito no trabalho!

\section{Gabriela Gonçalves}

Fonte: Subprojeto 3 "Treinamento e Qualidade de Vida e Estresse no Trabalho" realizado pelo Núcleo de Excelência do Instituto de Psicologia da Universidade de Brasília. 
Vivemos em um tempo de enormes exigências de atualização, sobre pressão da família, do meio social, do tempo, do trabalho ou da escola, portanto, constantemente temos de lidar com mudanças e tensões. Nos vemos cada vez mais diante de situações às quais precisamos nos adaptar, sejam responsabilidades, obrigações, críticas, dificuldades físicas e psicológicas.

Estes fatores podem ser suficientes para o desenvolvimento do processo de estresse em pessoas que sejam vulneráveis ou predispostas a desenvolvê-lo. Quando o processo de adaptação está exausto, nossas resistências caem completamente, abrindo as portas para as doenças.

Estudos mostraram que o sistema imunológico trabalha enfraquecido quando está sob o efeito do estresse, tornando o corpo mais vulnerável a doenças. O estresse pode causar problemas, que vão da asma, às doenças dermatológicas, alérgicas e imunológicas.

O estresse aumenta a probabilidade de contrairmos uma infecção bacteriana ou viral, inclusive um resfriado comum. Também aumenta nossas chances de sofrer uma doença degenerativa séria, como doenças cardíacas, pressão alta, câncer, asma, diabetes, doenças inflamatórias do intestino como também esclerose múltipla, artrite reumatóide e outras doenças auto-imunes. Aquelas pessoas que são cronicamente tristes, estão continuamente deprimindo seus sistemas imunológicos.
$\mathrm{O}$ efeito pode ser ainda maior em pacientes cujos sistemas imunológicos já estão comprometidos, como as pessoas infectadas com o HIV, o vírus da Aids, as quais são sempre de alto risco para doenças letais. Outro estudo mostrou que o estresse grave amplia a chance de sobreviventes de câncer de mama terem uma recaída do tumor.

$\mathrm{Na}$ área do sistema digestivo, o estresse pode desencadear desde uma simples gastrite, até uma úlcera.

A herpes, por exemplo, aparece quando as pessoas portadoras do vírus estão estressadas. Vírus como os da herpes e do HIV são capazes de se esconder dentro das células onde permanecem adormecidas até que o sistema imunológico se enfraqueça, momento em que ele prepara um ataque.

Certos hormônios relacionados ao estresse contribuem diretamente com as doenças cardiovasculares. Alguns desses mesmos hormônios criam também disfunções do sistema imunológico.

$\mathrm{O}$ estresse pode ter diferentes origens. $\mathrm{O}$ estresse de longo-prazo, como o relacionado à lembrança de acontecimentos traumáticos, pode debilitar muito a capacidade do corpo de enfrentar uma infecção, se esses pensamentos ou lembranças forem mantidos presentes na mente, pois acabam agindo no sistema imunológico da pessoa.

Liriane Piffero

Fonte: International Stress Management Association
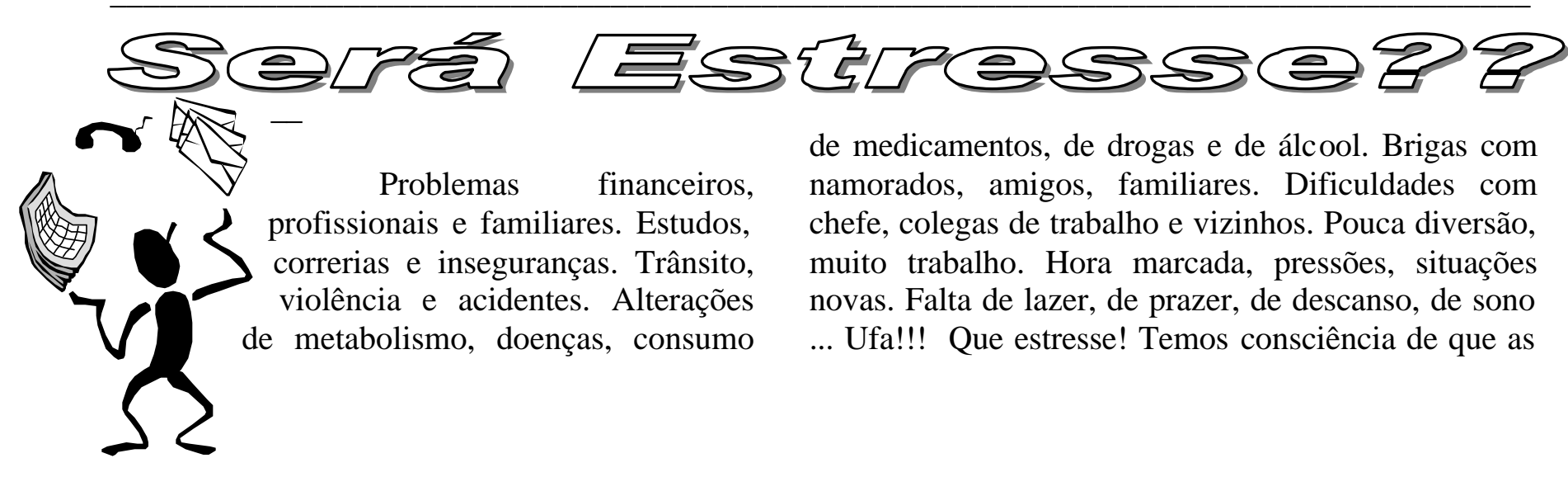

de medicamentos, de drogas e de álcool. Brigas com namorados, amigos, familiares. Dificuldades com chefe, colegas de trabalho e vizinhos. Pouca diversão, muito trabalho. Hora marcada, pressões, situações novas. Falta de lazer, de prazer, de descanso, de sono ... Ufa!!! Que estresse! Temos consciência de que as 
SUFOCANDO O ESTRESSE

coisas não são fáceis. Passamos por fases em que chegamos no nosso limite. Fases em que parece que o mundo todo está contra nós, em que tudo está dando errado, em que somos cobrados e reprimidos por diversos lados. Passamos por momentos duros, por pressões constantes, por tarefas que nos exigem demais. É..., o estresse virou moda. Afinal, quem nunca ouviu falar dele? Quem nunca se sentiu "estressado"?

O estresse nada mais é do que um conjunto de reações psicofísicas desenvolvidas quando temos que passar por algum tipo de adaptação. Ele, na verdade, é um mecanismo necessário e benéfico ao organismo, uma vez que atua como fator motivador e estimulante. E essa é a novidade! As pessoas tendem a encarar o estresse como algo maléfico, que nos causa tormento, angústia, depressão. E ele, realmente, pode ser, se estiver em um nível muito elevado.

No decorrer de nossas vidas, aprendemos a conviver com diversos estímulos (positivos e negativos) e tentamos canalizar as nossas reações. Uma vez que cada pessoa possui um limite
Porto Alegre, 15 de Agosto de $2003\lfloor 10$ determinado para administrar os estímulos a que fica exposta, o grande problema se dá quando se perde o controle da situação. Aí, as altas e constantes pressões acabam sendo prejudiciais à mente e ao corpo do indivíduo "estressado". Isso quer dizer que não é necessário abolir todos os nossos problemas para que tenhamos uma boa qualidade de vida. Basta que cheguemos a quantidade certa de estímulos, na qual conseguimos administrá-los sem que haja sobrecarga. Mas será que as pessoas têm conseguido tal façanha?

Pensando nisso, consultamos uma série de fontes e trouxemos para você um teste que mede o grau de estresse dos indivíduos. Tal questionário foi extraído do livro "Vencendo o Estresse", editora Makron, cuja autora, Thaís Helena Delboni, é especialista no tratamento e na prevenção do estresse. As perguntas são bem simples, e o teste pode ser feito rapidamente. Responda, tomando como base a legenda abaixo, some as respostas e descubra se você está sabendo controlar as suas reações, ou se faz parte da multidão de "estressados"!

\section{$\mathrm{A}$ - Freqüientemente $=\mathbf{4}$ pontos \\ $B$ - Algumas vezes $=3$ pontos}

\section{C - Raramente \\ D - Nunca}

\begin{tabular}{|l|l|l|l|l|}
\hline A & B & C & D & \\
\hline & & & & \multicolumn{1}{c}{ As idéias parecem ter desaparecido de sua mente? } \\
\hline & & & & Comer tem sido o seu maior prazer? \\
\hline & & & & Cumprir seus horários de trabalho tem sido difícil? \\
\hline & & & & Dores de cabeça tem sido freqüentes em sua vida? \\
\hline & & & & Está cada vez mais difícil dar andamento aos seus trabalhos? \\
\hline & & & & Não tem mais o desejo sexual de antes? \\
\hline & & & & O dia passa e você nem percebe que esqueceu de se alimentar? \\
\hline & & & & Pensar em ir trabalhar é uma idéia torturante? \\
\hline & & & & Programas que antes o agradavam tornaram-se verdadeiros martírios? \\
\hline & & & & Sente muita dor nos ombros ou na nuca? \\
\hline & & & & Sente vontade de chorar por qualquer motivo, está hipersensível? \\
\hline & & & & Sente-se cansado logo ao acordar? \\
\hline & & & & Sente-se profundamente desanimado com a vida? \\
\hline & & & & Sua memória está falhando? \\
\hline & & & & Sua pele parece ter perdido o brilho? \\
\hline & & & & Tem apresentado queda de cabelo? \\
\hline & & & & Tem dormido mal ultimamente, como se o sono não fosse repousante? \\
\hline & & & & Tem se resfriado com muita freqüência? \\
\hline & & & & Tem sentido fortes dores nas costas? \\
\hline & & & & Tem sido cansativo explicar a sua equipe idéias e projetos novos? \\
\hline & & & & Tem tido problemas de digestão? \\
\hline & & & & Você tem sentido seus olhos cansados ou vermelhos com freqüência? \\
\hline & & & Você tem tomado mais café do que o normal? \\
\hline
\end{tabular}


(49 a 25 pontos) Pouco Estressado - Que bom! Tudo parece ir bem para você! Porém, para se manter assim é bom prestar atenção às suas necessidades. Lazer é fundamental na vida de todos. Ninguém sobrevive somente trabalhando! Cuide-se agora! Atente-se ao seu equilíbrio físico e mental. Assim, estará evitando complicações futuras!

(74 - 50 pontos) Médio Estressado - Você é um forte candidato ao estresse. Está na hora de começar a se cuidar! Compreenda melhor a si mesmo e será capaz de "curar" a sua vida, evitando que o acúmulo de tensões culmine em problemas mais sérios. Intensifique seus momentos de lazer, faça atividades físicas, relaxe, dê mais tempo a si mesmo!

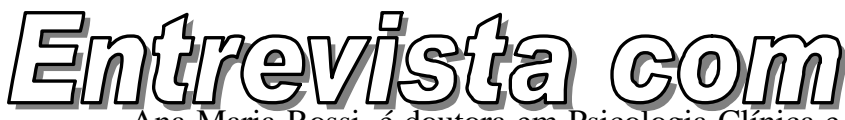

Ana Maria Rossi é doutora em Psicologia Clínica e Comunicação Verbal e dirige a Clínica de Stress e Biofeedback, em Porto Alegre. Ela é precursora das técnicas de autocontrole e biofeedback no Brasil e presidente da International Stress Management Association (ISMA) no Brasil.

Carolina: Que dicas você pode dar para uma pessoa que trabalha num ambiente de alta pressão e que não gosta do que faz, mas precisa fazer para sobreviver?

Ana Maria Rossi: Em Primeiro lugar, achar uma coisa positiva. Pode ser ambiente, o grupo, o salário, porque senão termina com pressão arterial alta, entre outros sintomas. Também é preciso canalizar as suas pressões, tensões de forma positiva, através de um exercício físico, socializando com amigos, fazendo um trabalho voluntário que goste.

Carolina: O que todo mundo quer é viver melhor, trabalhar menos, ter mais qualidade de vida. Existe uma chave para isso acontecer com pessoas normais ou apenas para os que contam com muita sorte na vida?

Ana Maria Rossi: Varinha de condão não tem. Qualidade de vida é um investimento. Requer que a pessoa dê prioridade a si mesmo: sono reparador, alimentação saudável, exercício físico regular, uma vida social ou familiar ativa e são todas atividades que consomem tempo, não é?

Carolina: Então, quer dizer que trabalho voluntário ajuda a “desestressar"?

Ana Maria: O trabalho voluntário ajuda porque a pessoa faz aquilo por prazer, faz porque quer e, quando o profissional consegue desempenhar a sua atividade profissional como uma atividade voluntária, ele tem uma situação ideal.

Carolina: Um dos grandes problemas da humanidade é a falta de tempo... por mais que a pessoa seja organizada. A falta de tempo estressa também?

Ana Maria Rossi: A falta de tempo é o fator número 1 de stress no mundo adulto, por isso é tão importante que as pessoas tenham objetivos definidos e que se organizem para dar prioridade aquilo que realmente é importante para elas.
(100 - 75 pontos) Muito Estressado - É bom procurar um especialista para ajudá-lo a lidar melhor com as situações estressantes de sua vida. Tudo indica que você já ultrapassou seus limites de tolerância e está bem estressado. Compreender o porquê de suas tensões irá ajudá-lo a modificar seus comportamentos e a tornar a sua vida mais saudável. Comece a melhorar sua qualidade de vida já!

Fonte: Vencendo o Estresse de Thaís Delboni Por Luísa Ludwig

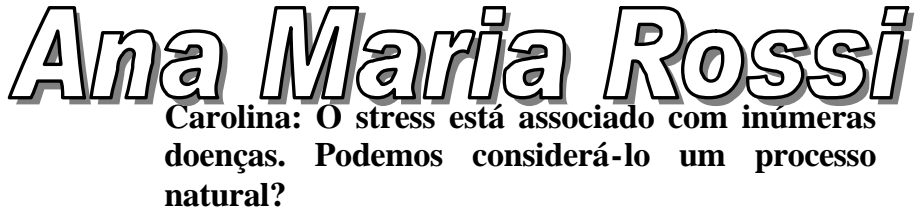

Ana Maria Rossi: O stress é parte da nossa vida, ele é essencial e inevitável. No entanto, quando ele supera as condições do indivíduo lidar com ele com eficiência, a pessoa tem um custo e normalmente este custo é saúde. Algumas doenças estão diretamente relacionadas com o stress e outras indiretamente, mas de qualquer forma o stress é parte de todos os tipos de doença porque ele afeta diretamente o nosso sistema de imunidade.

Carolina: Estou passando por uma fase bastante estressante. Sinto-me muito dispersiva, sem concentração ... O que devo fazer?

Ana Maria Rossi: Em primeiro lugar, iniciar uma técnica de relaxamento, sugiro que seja a respiração abdominal, similar aos bebês. Inspira pelo nariz para filtrar as impurezas do ar e imagina que está inflando um balão. Depois, expira pelo nariz ou pela boca e esvazia o balão. Em segundo lugar, avaliar o que pode mudar na rotina para diminuir o nível de stress e procurar manter as horas necessárias de sono para descansar e uma alimentação saudável para não contribuir com estímulos como cafeína, açúcar refinado etc...

Carolina: Você se considera uma pessoa estressada? Já sofreu de estresse? O que fez para corrigir este mal?

Ana Maria Rossi: Eu sou extremamente estressada, inclusive quando fui morar nos EUA em 1974 iniciei como cliente num programa de controle do stress. Senti tantos benefícios, estando em controle da minha vida que troquei minha atividade profissional como jornalista e advogada para psicóloga, especialista em stress. Nos 16 anos que vivi nos EUA, tive muitas oportunidade de aprender, praticar e ensinar técnicas de autocontrole sendo que a mais importante é a respiração abdominal. Também pratico Yoga diariamente e sou corredora de longa distância. Acho que controle do stress não é feito por uma única ação, mas um conjunto de vivências que determinam nossa qualidade de vida. 
Carolina: Estresse tem cura?

Ana Maria Rossi: Certamente. Cura tem, o que não tem é a varinha de condão. A pessoa quer avaliar o seu nível de stress e mudar o seu estilo de vida para que ela possa viver em harmonia com ele e este é o grande desafio.

Carolina: Podemos conviver com o stress, como convivemos com outras situações e isso pode ser um fator positivo, de alguma maneira?

Ana Maria Rossi: Sem dúvida, nós podemos aprender a lidar com stress de uma forma harmônica e eficiente que nos possibilite atingir nosso potencial. A maneira como a pessoa vai interpretar a realidade é que determinará se o stress será positivo ou negativo. No caso, se ela será motivada ou intimidada a lidar com a situação.

Carolina: Você tem mais alguma coisa que consideraria importante dizer para os nossos leitores?

Ana Maria Rossi: Gostaria de lembrar as pessoas que mesmo quando não temos controle sobre a situação causadora de stress, ainda podemos controlar a maneira como reagimos a esta situação.

Carolina Wosiack

Fonte: chat realizado no dia 01/11/2001 no Terra

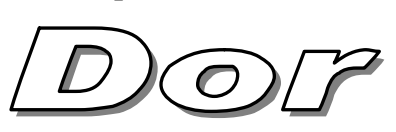

Em resposta às condições de vida de uma pessoa estressada pode haver reações como dores físicas sem correspondente orgânico e manifestações clínicas que são comumente tratadas como "só psicológicas". Como o estresse é uma doença de difícil diagnóstico deve-se ficar atento a sintomas como fadiga, falta de ânimo, falta de limites nas horas trabalhadas, sonolência ou ausência de perspectiva. Pode parecer exagero, mas tudo isto é causado pelo estresse.

O primeiro sintoma, a fadiga, é o mais comum. Este sintoma se manifesta quando realizamos algum esforço físico ou mental prolongado ou repetido, levando a diminuição do rendimento no trabalho. A sensação de fadiga vem acompanhada de cansaço, exaustão, fraqueza, dores musculares, ansiedade, falta de ânimo, desatenção, irritabilidade e diminuição do interesse sexual. Estes fatores causam dificuldade de tomar decisões e comprometimento da memória, o que pode gerar uma série de problemas no ambiente de trabalho.

A fadiga se inicia com alguma tensão. Sempre que temos uma tarefa a cumprir, surge tensão, que só é dissipada quando é alcançado o objetivo. Algumas vezes isto é impossibilitado por fatores que fogem ao controle e acabam, então, levando o indivíduo à exaustão. No trabalho, tal processo não deveria acontecer. Partindo do pressuposto que o trabalhador execute uma função sobre a qual tem conhecimento e pela qual sente grande apego, não deveria haver tensões impossíveis de serem solucionadas. A solução gera motivação e satisfação ao indivíduo que teve o seu dever cumprido. Infelizmente, nem sempre é assim. Em muitos casos, há falta de interesse pela função a ser exercida diariamente, e então, o trabalho não alivia a tensão, que se acumula causando mais tensão e podendo levar à fadiga.

Outros problemas que surgem em decorrência do esforço excessivo para realização de uma tarefa são os distúrbios do sono, classificados como insônia, sonolência excessiva, distúrbio do padrão sono - vigília e parasonia. $\mathrm{O}$ primeiro distúrbio é, na maioria das vezes, transitório, e se manifesta devido a uma situação de estresse que esteja sendo enfrentada. A sonolência excessiva é um meio de fuga dos problemas vivenciados diariamente. A pessoa dorme para postergar a busca pela solução. Os distúrbios do padrão sono - vigília ocorrem, normalmente, devido a mudanças nos turnos de trabalho. O último distúrbio é a parasonia, que se manifesta através do bruxismo (ranger dos dentes), do sonambulismo, do terror noturno e de enxaquecas. Estes são alguns meios de alarme sobre a situação de estresse em que a pessoa se encontra.

Dentre tantas manifestações de estresse, algumas pessoas passam a se refugiar dos conflitos no trabalho se tornando workaholics, isto é, se tornam viciadas em trabalho. Estas pessoas desaprendem a usar seu tempo livre e, quando não estão trabalhando, têm problemas de relacionamento com familiares e amigos. Isso sem falar da possibilidade de aparecimento de doenças coronarianas e de grande liberação de hormônios como a adrenalina, que modificam o normal funcionamento cardíaco. A perda de controle se dá pela grande demanda de tarefas a serem executadas pelo trabalhador: esforço para aumentar a produção no curto prazo com diminuição dos custos, grande carga de trabalho, competição entre colegas de trabalho e extensão da jornada trabalhada. O resultado disso é estresse intenso e prolongado, aumentando o risco de doenças cardiovasculares que podem levar à morte.

Outra consequiência do estresse é conhecida como burnout, um desgaste físico e mental capaz de levar qualquer pessoa à exaustão. A pessoa se dá conta de que não possui mais recursos para dar aos outros. Fica irritada, cansada, ansiosa e propensa a causar acidentes pela falta de atenção. Passa a tratar os outros como objetos, ao mesmo tempo em que tem resultados inferiores ao normal e possui falta de prazer de viver.

O burnout é o último estágio do estresse, onde, definitivamente, a "dor" não é psicológica. Se a pessoa estiver sentindo alguns desses sintomas, deve admitir que algo está errado e procurar ajuda médica, impedindo que a dor psicológica se transforme em dor física, acompanhada de doenças graves e muitas vezes incuráveis. Prestando atenção aos sintomas, o estresse pode ser diagnosticado a tempo de se evitar consequiências mais graves e assim não trazer grandes perdas para o trabalhador nem para a empresa.

Fonte: LIMONGI FRANÇA, Ana Cristina e RODRIGUES, Avelino Luiz. Stress e trabalho: guia básico com abordagem psicossomática. Atlas, 1996. 


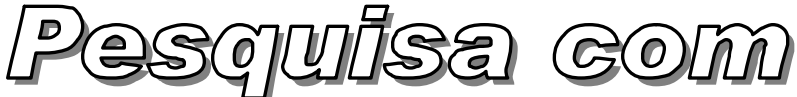

É mais do que sabido que altos graus de estresse têm se mostrado constantes na vida das pessoas. Os mais atingidos por esse mal, geralmente, são as pessoas mais atarefas, cheias de compromissos, pressões e responsabilidades. Tendo isso em mente, resolvemos fazer uma pesquisa no campus central da UFRGS para verificar se os estudantes da nossa universidade fazem parte dessa multidão de estressados.

A partir daí, diversos testes de profissionais conceituados e de especialistas no assunto foram consultados. Escolhemos uma pesquisa com 11 questões simples elaboradas pelo INDEPE (Instituto de Desenvolvimento da Pessoa), uma empresa de consultoria voltada para a promoção e a manutenção da saúde organizacional. A pesquisa foi aplicada em 40 estudantes, e cada um deles teve que atribuir às perguntas um número, representando a intensidade com que eles perceberam cada questão nos últimos dois meses. As perguntas citavam a habilidade em tomar decisões, a eficiência e a qualidade no trabalho, o relacionamento do entrevistado com as pessoas vinculadas a eles, a manifestação de indícios de tédio, depressão ou angústia, e o controle emocional, entre outros pontos. E então, quer saber qual foi o resultado?

Bem, confessamos que foi um tanto surpreendente! Devido à constante ameaça de greve, à carência de verbas, às manifestações existentes ao redor da universidade, aliadas, também, aos estudos, aos trabalhos e à "vida social" que, nessa idade, os estudantes costumam enfrentar, nós acreditávamos que o nível de estresse seria mais elevado do que se apresentou. Mas, pelo jeito, estávamos enganadas porque, mesmo diante desses fatores, parece que boa parcela dos alunos não têm sentido tanta pressão.

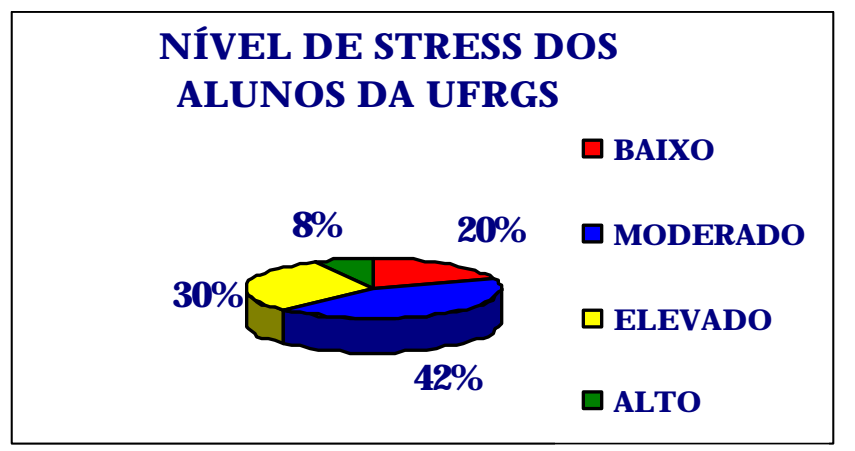

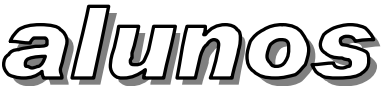

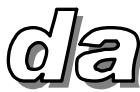 \\ UIFRTS}

Como se pode notar no gráfico acima, cerca de $20 \%$ dos entrevistados apresentaram um estresse mínimo; 42\%, um grau moderado; $30 \%$, elevado, e apenas $8 \%$ dos universitários ficaram enquadrados no nível de estresse alto, indicativo de graves problemas de saúde.

Analisando uma a uma as questões, verificamos que nas referentes à queda de eficiência e à depressão e/ou tédio sem motivo aparente, a incidência foi grande. No entanto, nenhum ponto foi tão citado como a vontade de ficar na cama pelo resto do dia - próprio da idade, possivelmente. Ao contrário, o tópico que obteve menor média de ocorrência foi o que diz respeito à perda do interesse sexual. Aí, se as respostas foram verdadeiras, não há como saber, mas que já eram esperadas, isso eram!

Já em relação à forma como o teste foi elaborado, há certa divergência. E isto é até engraçado. Em geral, os pesquisados aprovaram o questionário. Acharam que era simples, prático e adequado para o seu fim. Nada de surpreendente. Afinal, a grande maioria dos que responderam à pesquisa eram alunos dos cursos de Administração, Ciências Contábeis, Ciências Atuarias e Economia (mais exatos que humanos). Contudo, tal visão não é unânime. Para uma aluna de Psicologia da PUCRS, o teste, em parte, não atende ao seu propósito. Segundo a estudante, não há como classificar alguém em um desses níveis de estresse, baseando-se apenas em 11 perguntas que são simples e muito abrangentes. Além disso, o teste é resumido demais, generaliza as pessoas e tem critérios de classificação não muito adequados. Por exemplo, imagine uma pessoa que goste de comer e de dormir bastante. Ela tem um(a) namorado(a), mas não gosta mais dele(a) como no início do relacionamento. Em vista disso, não tem mais tanta vontade de manter relações sexuais com o seu companheiro(a). Pois bem, segundo o teste, essa pessoa se encaixaria no nível de estresse moderado, devendo ficar alerta! Agora, me responda: o pesquisado não poderia apenas ser guloso e preguiçoso por natureza? E ele não tem "direito" de não desejar mais da mesma forma aquele de quem ela não gosta mais? Dá para perceber a impessoalidade que o questionário apresenta?

Pois é ..., a realidade é que "cada caso é um caso". Assim, os estudantes que apresentaram um nível baixo de estresse podem, de repente, estar até mais estressados do que aqueles que fizeram uma pontuação maior. E, aqueles que tiveram alto estresse como resultado, não precisam, necessariamente, sair correndo à procura de ajuda. O importante é que estejam atentos aos sinais do corpo, lembrando que simples indícios isolados não declaram que o indivíduo é um estressado-nato. Antes de tudo, devemos observar o contexto em que se dão os possíveis indícios de estresse e, a partir daí, tomar as devidas providências. Então, esteja atento. E, se o estresse surgir, relaxe!

Fonte: www.indepe-sp.com.br/qualidad.htm

Luísa Ludwig 


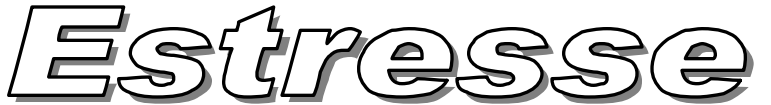

Estressores sociais são acontecimentos de nossas vidas que se revelam quando não alcançamos no trabalho a satisfação de determinadas necessidades. Além de saúde, dinheiro e segurança, encontram-se entre as necessidades o progresso na carreira, o reconhecimento, o status no meio social no qual vivemos e a satisfação com o trabalho em si. Se não satisfizermos estas necessidades ditas pessoais, o ambiente de trabalho se tornará desgastante.

Sobre a segurança, uma das necessidades básicas dos indivíduos, basta estudar a sociedade na qual vivemos para perceber o quanto ela é importante, e quanto sua falta pode gerar estresse. Vivemos numa sociedade na qual riqueza é sinônimo de status e competência profissional. A incerteza quanto à permanência no emprego gera instabilidade na vida do trabalhador, que se estressa com a possibilidade de perder o respeito dos familiares e colegas ou de ter que baixar seu padrão de vida caso perca o emprego. O pior é que esta necessidade dos trabalhadores entra em conflito com a necessidade da organização, que é o lucro. Para alcançá-lo, a organização trata o trabalhador como uma peça descartável no processo produtivo. Este conflito é responsável por uma boa parte do estresse gerado no trabalho.

Outro fator que provoca estresse no trabalho pode ser ilustrado através da Teoria dos Papéis. Papel é a função que um indivíduo exerce em determinado momento, podendo ser de chefe, de subordinado, de mãe, de irmã e de filha ao mesmo tempo. Qual o papel que devemos desempenhar depende de características pessoais, mas nem sempre, na organização, somos orientados com clareza sobre isto. Com certeza, esta falta de definição sobre qual é o nosso papel acaba gerando estresse. Estes problemas se classificam em ambigüidade, incompatibilidade, conflito e sobrecarga de papéis. No primeiro caso, quando há ambigüidade de papéis, o estresse surge pois a pessoa encontra dificuldade de saber quais tarefas lhe cabem cumprir, até onde vai sua responsabilidade sobre a execução destas tarefas e quais as metas que deve alcançar. Já na

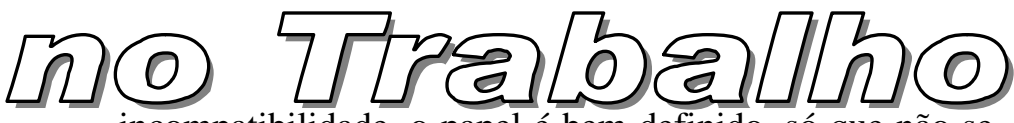

incompatibilidade, o papel é bem definido, só que não se encaixa com as características da pessoa encarregada de

desempenhá-lo. Outro caso é o conflito somado com a incompatibilidade de papéis, que ocorre quando alguém precisa desempenhar dois papéis distintos e um acaba se sobressaindo. Por exemplo, uma mãe, chefe autoritária de uma empresa, acostumada a mandar e desmandar nos empregados, transfere essa postura para dentro de casa, fazendo o mesmo com o marido e com os filhos. $\mathrm{O}$ conflito entre papéis é estressante não só para quem o desempenha, mas também para quem convive com esta pessoa. Também a sobrecarga de papéis faz com que um se sobressaia, e deve ser eliminado assim que possível com delegação de funções a pessoas capacitadas. Isso ocorre normalmente quando as empresas estão em transição de comando, ou quando um executivo é promovido. Sabendo todos estes estressores sociais que são encontrados no trabalho, pode-se encaixar a frase de Dejours, que diz que: "Não há trabalho sem sofrimento".

Sendo assim, resta saber como lidar com o estresse organizacional. A empresa pode adotar uma estratégia de combate ao estresse, obedecendo, a princípio, a ações dirigidas ao caso de cada trabalhador, afinal o estresse é uma relação entre o indivíduo, o ambiente e as circunstâncias em que ele se encontra. Para escolher a estratégia mais adequada de combate ao estresse é necessário que se faça pesquisa para determinar como anda o nível de estresse na empresa. Se a pesquisa for bem fundamentada, os resultados podem colaborar para a busca de uma melhora na qualidade de vida dos trabalhadores. Deste modo, as manifestações de estresse não devem ser consideradas de todo malignas. Elas servem de alarme para que a pessoa procure se adaptar às condições em que vive e transforme o trabalho em fonte de satisfação e realização pessoal. Com as diversas maneiras que existem hoje para combater o estresse, a doença está cada vez mais fácil de ser tratada, mas ao mesmo tempo, há um aumento do número de pessoas estressadas. É uma dicotomia que, pelo menos por enquanto, não tem solução.

Fonte: LIMONGI FRANÇA, Ana Cristina e RRODRIGUES, Avelino Luiz. Stress e trabalho: guia básico com abordagem psicossomática. Atlas, 1996 
As empresas investem na qualidade de vida dos funcionários evitando o estresse. Diversas organizações no mundo todo possuem hoje programas que visam prevenir as doenças de seus funcionários, e o estresse tem uma papel de destaque dentre elas. As pressões sofridas em decorrência de prazos cada vez menores, das exigências do mercado, da competição interna nas organizações e das variações econômicofinanceiras, levam a maioria das pessoas a um estado de enrijecimento muscular e de exaustão mental que, ocorrendo repetidas vezes, esgota as reservas físicas e emocionais dos indivíduos.

Para terminar ou pelo menos diminuir os casos de estresse nos locais de trabalho, as organizações estão procurando atuar não somente como sustentáculos financeiros de seus funcionários, mas também como agentes a favor de uma melhor qualidade de vida de seus colaboradores. Essa preocupação, tem feito as empresas investirem cada vez mais em benefícios e em melhores condições de trabalho. As organizações começam a ver a necessidade de uma análise completa da empresa, para garantir seu desenvolvimento e torna-se evidente que os investimentos no ser humano das empresas trazem um enorme retorno no nível da qualidade $\mathrm{e}$ produtividade para a própria empresa. A tranquiilidade física e emocional das pessoas passou a ser sinônimo de crescimento organizacional.

Cabe aos dirigentes de empresas desenvolverem atitudes e programas específicos que possam minimizar o efeito dos fatores sociais e organizacionais causadores do estresse nos funcionários. A organização moderna mantém-se constantemente ocupada com projetos que visam melhorar as condições de vida de seus colaboradores, pois isso, segundo a filosofia das empresas alemãs, implicará em pessoas mais felizes e produtivas.

São diversos os fatores que implicam melhoria da qualidade de vida das pessoas dentro da organização. O local de trabalho, por exemplo, representa um dos fatores mais importantes para o bom desempenho de uma função. Ambientes claros, ventilados, bem-iluminados, mobiliados adequadamente e limpos, representam condições mais sadias de trabalho, facilitando e motivando aos funcionários desempenhar corretamente suas tarefas.

$\mathrm{O}$ investimento em programas de desenvolvimento profissional e pessoal também minimiza as dificuldades encontradas no dia-a-dia, fornecendo novas ferramentas de trabalho e melhorando as relações inter-pessoais. Políticas de acompanhamento de pessoal, realizadas por um órgão de recursos humanos forte e participativo, colaboram para a eliminação de pequenos problemas e prevenção de tantos outros, além de garantirem aos funcionários a certeza da possibilidade de expressarem seus anseios, dúvidas e dificuldades.

Outro fato importante, observado pelas organizações atuais e que colabora para a instalação de um processo de estresse, é a tensão causada aos funcionários para conseguir cumprir seus horários de trabalho convenientemente, o que levou as empresas a adotar um sistema de transporte coletivo.

A criação de refeitórios modernos e bem equipados dentro das empresas, gerenciados por nutricionistas capacitados e o investimento na área de saúde, com a presença diária de médicos e enfermeiras prestando atendimento e esclarecendo dúvidas aos funcionários, além de um importante benefício para o funcionário, garante à empresa os resultados desejados e a diminuição dos dias de trabalho perdidos por falta ou doenças.

Para evitar ainda mais essas faltas ao trabalho, as empresas fazem convênios com planos de saúde médicos e odontológicos para o funcionário e familiares e, além disso, investe na construção de modernas creches, administradas por pessoas especializadas, que garantem ao funcionário tranqüilidade quanto ao bem-estar de seus filhos e, conseqüentemente, permitem-lhe desempenhar melhor suas atividades.

A empresa também deve, por meio de políticas de comunicação, deixar extremamente claro os seus objetivos e os caminhos pelos quais a organização vai se desenvolver. Assim, será muito mais fácil contar com a colaboração de todos, pois combater o estresse, antes de tudo é preciso re-aprender a interagir com pessoas e reagir saudavelmente diante das ocorrências da vida. É possível controlarmos os sintomas, mas é necessário que as causas sejam sanadas para que o processo não se reinicie.

Rafaella Tabajara 


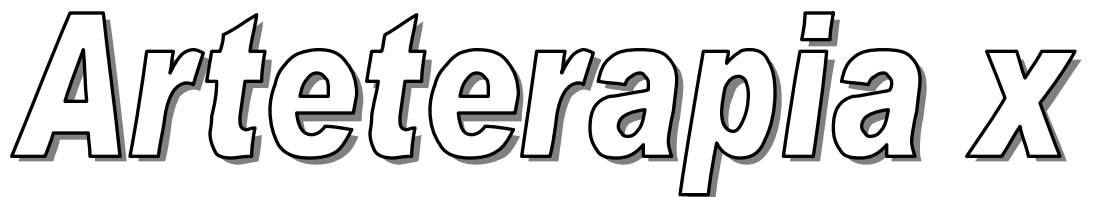

A areterapia é um território para onde confluem diferentes campos de conhecimento: a Arte, a Educação e a Psicologia e constitui-se num instrumento de transformação social e pessoal, capaz de auxiliar na construção de um mundo melhor através da formação de homens mais éticos e mais comprometidos.

Aprendemos com a nossa prática, que toda pessoa tem condições de realizar um trabalho expressivo e que todo trabalho expressivo vem repleto de vivências pessoais e culturais do indivíduo. Assim, através das atividades expressivas, pode-se construir e reconstruir a subjetividade; pode-se fornecer suportes materiais para que a energia psíquica plasme símbolos em criações diversas, que seriam indicativos dos múltiplos estágios da essência de cada um, ativando a comunicação entre inconsciente e consciente e colaborando para a compreensão e resolução de estados afetivos conflitivos, culminando na busca do espaço sagrado.

Ao realizarmos atividades expressivas, rompemos com a rotina do cotidiano, por vezes automática e estabelecemos novas relações entres seus elementos, estruturando o velho com o novo, o conhecido com o sonhado, o temido com o vislumbrado, desta forma, possibilitando nova integração e crescimento.

De todas as características mencionadas, uma das que mais nos interessa é a de resgatar a qualidade de vida através da possibilidade de reconciliar conflitos emocionais já que estes estariam ligados ao do estresse. Indo além destes aspectos, relembramos também, que as atividades expressivas utilizam-se de uma linguagem pré-verbal (no sentido de que reconhecemos imagens antes de aprender a falar). A linguagem pré-verbal é uma linguagem mais regressiva $\mathrm{e}$ facilitadora de contato, portanto, favorecendo a emergência de conteúdos mais profundos. É também uma linguagem mais individual, em que signos e símbolos são escolhidos e/ou criados pelo indivíduo (Selma Ciornai in A Arte Cura, 1995).

A mesma autora citada acima, coloca que a linguagem verbal é mais linear, é causal, lógica, temporal e espacial. $\mathrm{Na}$ nossa intimidade psíquica, há um mundo de percepções e sensações que ocorrem ao mesmo tempo, tais como, pensamentos, sonhos, fantasias, visões, que não respeitam necessariamente a ordenação lógica e temporal da linguagem. Assim, as linguagens plástica, poética e musical parecem ser mais adequadas a expressão do que ainda é nebuloso, complexo e que implica uma captação de vários níveis de significado.

A arteterapia, através da utilização de diferentes atividades expressivas pode promover o estabelecimento de um "território sagrado", um espaço de proteção, local para renovar forças, verdadeira casa no sentido psíquico" constituir-se-ia num local e tempo de criação, de resgatar e expandir potencialidades adormecidas, de desvelar sentimentos; local e tempo de compreender conteúdos inconscientes e de questionar valores. As atividades expressivas tencionam

dar forma, e materialidade ao que é intangível, difuso, desconhecido ou reprimido como: sonhos, conflitos, desejos, afetos, energia psíquica que é bloqueada e precisa liberar-se e fluir para poder plasmar e

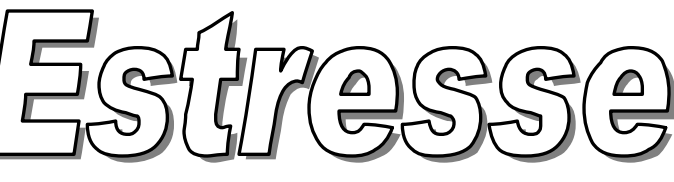

configurar símbolos que assim cumprem sua função de comunicar, estruturar, transformar e transcender.

Intentando romper com a rotina do cotidiano, proporcionar autoconhecimento e fortalecer o trabalho em equipe foi que se realizou uma atividade no dia primeiro de maio de 2002, com os funcionários do Café do Porto. Participaram todos os funcionários, garçons, cozinheira, barman, caixa e a própria dona do estabelecimento. Iniciou-se com um convite para que todos fizessem bolinhas de sabão na calçada do café, com o objetivo de descontrair e quebrar a rotina, voltando para a idade em que não havia tanta censura. Depois voltou-se para o interior do café e foi proposto que cada um pegasse uma fatia da mandala: um círculo de $90 \mathrm{~cm}$ de diâmetro foi cortado em várias fatias e cada um recebeu um pedaço que deveria pintar, colar com materiais diversos. Depois de cada um fazer sua parte, deveriam juntos montar a mandala da forma que ficasse mais harmoniosa. Antes de trabalharem em conjunto, cada um contava o que havia feito, como e porque, oportunizando um melhor conhecimento de cada membro do grupo. Quando terminado o grupo escolheu um local dentro do café para pendurarem a mandala.

Carolina Wosiack 

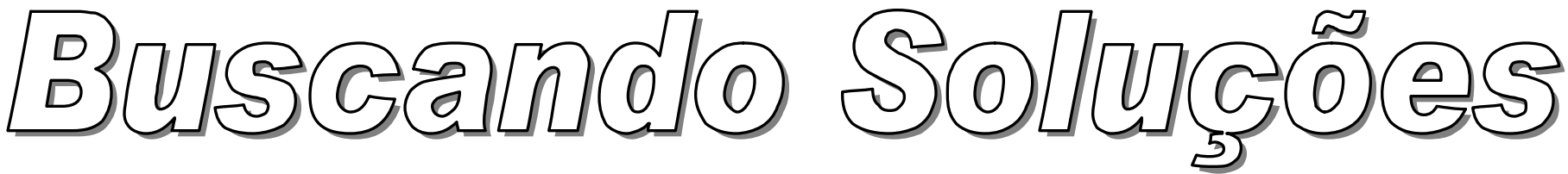

Milagres não existem. O bem-estar físico e mental requer trabalho, mas um trabalho agradável e descontraído que respeite seu estilo, seus limites e, principalmente, que seja fonte de grande prazer. Somente por extrema necessidade faça o que você não gosta e, assim que possível, pare!

Encontrar a paz interior implica conhecer a si mesmo: seus gostos, suas vontades, seus pontos fracos e fortes, sua fragilidade ou seu excesso de rigidez; poder olhar-se no espelho e realmente enxergar e reconhecer a imagem refletida.

Muitos são os caminhos para o auto-conhecimento ou simplesmente para melhorar nossa qualidade de vida. Você pode escolher caminhar só ou acompanhado na estrada de opções que buscam a sua saúde. Seja qual for sua escolha, certifique-se de que é o que você quer.

Todos os caminhos que buscam a harmonia do corpo e da alma sempre serão complementares, jamais um excluirá o outro, sendo muitas vezes necessárias ou mais eficaz, a associação de vários deles. A combinação de algumas dessas propostas de soluções pode se dar a medida que você sinta a importância de cada uma delas para o seu bem-estar físico e emocional.

Portanto, avalie e mude seus hábitos, buscando uma vida mais saudável e livre de estresse. Para isso aí vão algumas dicas:

- Alimente-se adequadamente. A alimentação correta é uma das garantias de boa saúde.

- Aprenda a delegar trabalho. Os outros também podem ser competentes!

- Da mesma forma que você deve chegar no horário na empresa, procure também não exceder seus horários de saída do trabalho.

- Estabeleça suas prioridades, não desperdice sua energia.

- Faça as coisas em seus devidos lugares: trabalhe na empresa e em casa descanse.

- Lembre-se de que lazer é fundamental. Inclua-o na sua vida, se possível diariamente.

- Poupe-se. Seja objetivo e claro.

- Lembre-se de que o dia tem 24 horas e cada hora tem 60 minutos (isso é muito tempo).

- Novos hábitos, novos prazeres e novos desafios são sinais de renovação. Sinais de evolução!

- Aprecie os pequenos prazeres da vida. Dê valor aos pequenos gestos, às coisas simples.

- Questione sempre se a qualidade de sua vida pessoal e profissional está boa. Em caso negativo verifique as falhas e faça o possível para mudar.

- Todos são perfeitos dentro de suas possibilidades; respeite suas capacidades e seus limites e os limites dos outros também!

- Viva um dia de cada vez. Portanto, lembre-se de que hoje é hoje, e não amanhã e nem ontem.

Rafaella Tabajara

Fonte: Livro "Vencendo o Estresse" de Thaís Helena Delboni, da Série "Saúde e Harmonia no Trabalho". 